\title{
Escaping the Middleman Paradox: Better Reykjavik and Open Policy Innovation
}

\section{Derek Lackaff}

School of Communications, Elon University, Elon, North Carolina 27244, dlackaff@elon.edu

\begin{abstract}
Better Reykjavik is a unique municipal ePetition website that is developed and maintained by a grassroots nonprofit organization, has significant deliberative mechanisms, and has been normalized as an ongoing channel for citizen-government interaction across multiple elected administrations. The primary contribution of this study is an analysis of the novel "interface" that was established between the grassroots-developed technical system and the existing political and administrative institutions of policymaking. The paper begins with a brief overview of the challenges that citizens and governments face in the implementation of ePetition processes. Landemore's (2012) “democratic reason” and Coleman's (2008) “autonomous citizenship" constructs provide useful insights into why and how the Better Reykjavik has made a continuing impact on city governance. Next, an analysis of the socio-technical process of the initiative's software development and political integration is presented, showing how this project moved from the fringes of the grassroots towards the center of public and governmental awareness. Finally Reykjavik's "new normal" political culture is examined, which illustrates how a bottom-up, fast-moving technical initiative can productively support the slower-moving processes of democratic governance.
\end{abstract}

Keywords: ePetitions, eDemocracy, eGovernance, crowdsourcing, cocreation, open innovation

Acknowledgement: The author gratefully acknowledges the support and cooperation of Gunnar Grímsson and Róbert Bjarnason, as well as the Elon University iMedia students of "Team Iceland" who conducted several of the initial interviews.

\section{Introduction}

Following an economic crisis which swept away much of their wealth, international regard, and trust in established political institutions, Icelanders were in a unique position to experiment with radical new approaches to governance and citizenship. As one of the world's most digital highlydeveloped nations (boasting not just a high internet access rate, for example, but also the one of the world's highest Facebook usage rates), many new Icelandic initiatives attempted to leverage digital platforms to improve governmental access, transparency, and accountability. 
One such project that has helped restructure the relationship between government and the citizens is called Better Reykjavik (Betri Reykjavik). On the surface, Better Reykjavik appears to be a straightforward ePetition site, similar to those now operated by governments around the world. I suggest that Better Reykjavik is unique among similar projects for three primary reasons: First, it is developed and maintained by a grassroots nonprofit organization, and not a government; second, it has significant deliberative mechanisms, unlike many other ePetition initiatives; and third, it rapidly achieved significant buy-in from citizens, policy-makers, and public administrators and has been normalized as an ongoing channel for citizen-government interaction across multiple elected administrations. The initiative has "escaped" the "middleman paradox" (Mahrer \& Krimmer, 2005) - where holders of political power are reluctant to yield it to eDemocracy processes - that has limited the success of similar projects.

This work is theoretically situated in the recent tradition of political communication and digital citizenship studies developed by Coleman et al. (2008; Coleman \& Blumler, 2009). Coleman's notion of "autonomous citizenship," describing political engagement processes that are promoted (but not entirely managed) by governments, provides a framework for understanding the success of Better Reykjavik initiative. Coleman (2008) describes eCitizenship as a technology of governance: Not governance "in the traditionally coercive and dominating sense", but one that "is about nurturing forms of conduct consistent with being a citizen" (p. 201). Although Coleman was primarily focused on youth citizenship practices, his formulation is appropriate for the broader context of Reykjavik's highly-connected citizenry. Further, the social value of policy crowdsourcing or ePetition websites, and of the system implemented by Better Reykjavik more specifically, can be usefully situated within Landemore's (2012) "democratic reason" framework. Landemore argues that democratic reason is "the kind of collective intelligence distributed across citizens and a certain number of institutions and practices that can be seen as specifics to democratic politics" (p. 8). The "social calculus" of collective democratic organization, Landemore finds, is best supported within a context of maximal social inclusion and participation. Better Reykjaviks' inclusive and distinctively informal origins provide a singular case for understanding the democratic reasoning process of a newlyempowered and potentially autonomous citizenry.

The primary contribution of this case study is an analysis of the "interface" that was established between the grassroots-developed technical system and the existing political and administrative institutions of policymaking. The analysis is drawn upon web analytics data from the Better Reykjavik site, interviews with citizens, administrators, and politicians completed since 2010, and archival data including newspaper reports, committee meeting minutes, and other public information. A brief overview of eParticipation as a contextual framework for understanding the initiative is provided, with a focus on some of the challenges governments face in their implementation processes. Landemore's (2011) “democratic reason" and Coleman's (2008) "autonomous citizenship" constructs provide useful insights into why and how the Better Reykjavik has made a continuing impact on city governance. Further, the socio-technical process of the initiative's software development and political integration, showing how the project moved from the fringes of the political grassroots towards the center of public and governmental awareness, is analyzed. Finally, Reykjavik's "new normal" political culture, showing how a bottom-up, fast- 
moving technical initiative can productively support the slower-moving processes of democratic governance is examined.

\section{2. eParticipation: Civic Engagement and Communication Technologies}

The potential of communication technologies to improve democratic civic engagement is perhaps one of the most lauded (and critiqued) tropes of social technology studies. As Coleman (1999) notes, there is a popular rhetoric of technological determinism that suggests that interactive media "possess inherently dialogical, democratic and libertarian characteristics, allowing political communication to return to the people" (p. 197). Where the old broadcast and print media maintained a tight hold on popular political discourse, as the pundits argue, the internet provides citizens with more information about the functioning of their polities, more opportunities to deliberate and discuss civic issues, and more channels for interacting with their governments. In the developed world, most major political parties have been forced to wholly embrace social media, but those outside the political mainstream are also successfully organizing and fundraising online. Energetic political movements from the edges of the political spectrum have made interactive communication with constituencies the foundation of their platforms.

Approaches to the civic utilization of information technologies have come from both the top down (official and governmental initiatives) and from the bottom up (community grassroots projects). Governmental initiatives often aim to provide more information and more transparency about the increasingly complex processes that comprise their functioning, generally referred to as eGovernance. Even as the administrative functions of governments have been increasingly moved online (as evidenced, for example, by the United Nations Global E-Government survey), governments have been much slower to move the deliberative and decision-making functions online and into the hands of constituents, to promote eParticipation and more direct (e)Democracy. Grönlund (2011) finds that "while automating government processes earlier was at the focus of eGovernment development, the explosive increase in use of social media has increased the requirements on eGovernment services to become 'citizen-centric,' including taking part in decision making, i.e. democratic participation" (p. 27). Grönlund argues further that eParticipation is a slippery concept, and that governments can use the trappings of eParticipation to paint a kind of "democratic gloss" (p.36) over eGovernment activities that are in reality not particularly democratic. Mahrer and Krimmer (2005) argue that the lag of participatory eDemocracy behind service consumption, eAdministration results primarily from the reluctance of politicians to relinquish power to citizens, and a skepticism or even fear of any agenda that promotes more direct democracy. This "middleman paradox" emerges "as the very same parliamentarians who would be responsible for introducing new forms of citizens' participation for political decision-making are explicitly and implicitly opposing these reforms" (p. 38). A major factor in Better Reykjavik's successful implementation was its ability to overcome this paradox, as will be illustrated later.

Based on their review of the literature, Sæbø, Rose, and Skiftenes Flak (2008) find that eParticipation encompasses a wide range of practices, agendas, theories, and models. eParticipation is broadly defined as the "technology-mediated interaction between the civil society sphere and the 
formal politics sphere and between the civil society sphere and the administration sphere" (p. 402). Sæbø et al. characterize eParticipation practice as consisting of five primary components:

- Actors (citizens, politicians, government institutions, voluntary organizations) that conduct

- eParticipation activities (e.g. eVoting, online decision making, eConsultation, ePetitioning) in the context of

- Contextual factors (e.g. information availability infrastructure, underlying technologies, governmental organization), that result in

- eParticipation effects (e.g. civic engagement, deliberation) determined through

- eParticipation evaluation (quantity, demographics, tone and style) (p. 417).

Many eParticipation initiatives have direct precedent in earlier forms of political participation: voting, petitioning, campaigning, consultations, deliberations, and lobbying each have centurieslong traditions in many contemporary democracies. In some cases, eParticipation may represent, primarily, a higher level of efficiency, immediacy, or access to these processes. Of particular interest in this paper, however, are eParticipation processes that may differ from their "offline" precedents in less intuitive ways. Among such processes is the case of policy crowdsourcing (Aitamurto, 2012).

Technical systems that facilitate mass-scale innovation are increasingly being deployed by companies and governments, and a range of terms have been coined to identify and describe these processes. The term crowdsourcing, popularized in the web business media of the mid-2000s, initially referred to the release of tasks or challenges to the public by actors with commercial or institutional power. The public is encouraged to submit solutions to the challenge, and the most successful or popular solutions are implemented or rewarded in some way. Although often applied to commercial endeavors such as product design, similar processes can be seen at work in the area of governance. In contemporary usage, crowdsourcing is often used to characterize a broader range of activities related to decentralized, digitally-mediated collaboration processes. Aitamurto \& Landemore (2013), for example, define crowdsourcing simply as "an open call for anyone to participate in an online task by submitting information, knowledge, or talent" (n.p.).

Such strategies to make use of the "intelligence" of large, distributed groups are increasingly being implemented by policy-making institutions to respond to and take advantage of constituents' perspectives and ideas (Brito, 2008). These strategies are often also promoted as a means to increase the transparency of governmental processes (Bertot, Jaeger, \& Grimes, 2010; Brito, 2008). Crowdsourcing can be viewed as a practice of "collective intelligence" (cf. Levy, 1997; Landemore, 2012) or "civic intelligence" (Schuler, 2001). Both concepts suggest the development of an emergent, distributed "intelligence" that resides among the interactions of people and their information infrastructure. In recent years, processes that can be termed crowdsourcing have been used in governance processes including planning (Brabham, 2009; 2012a; 2012b) and budgeting (Aitamurto, 2012).

Policy-focused initiatives, which invite the public to propose or deliberate upon specific proposals, have emerged at many levels of governance (national to municipal) and in many locations. Aitamurto (2012) summarizes several policy crowdsourcing projects, including the Icelandic constitutional revision process, the US Open Government national dialogues, participatory budgeting in Chicago and Calgary, and national ePetition sites in Finland and the US. The diversity 
of approaches to political crowdsourcing leads to some research challenges. Political initiatives characterized as "crowdsourcing" often seem to preclude many elements of deliberation. Aitamurto finds that most political crowdsourcing efforts generally promote a "one-time-shot, singular act of participation" by citizens, and that such initiatives are "focused on gathering people's opinions and ideas, rather than establishing spaces for deliberation, or designing incentives for the participants to deliberate to achieve consensus" (p. 31). Policy crowdsourcing, like most eParticipation initiatives, is subject to technical and socio-political challenges, including groupthink, participation theatre, empowering abuse, and promoting other forms of mischief.

\subsection{Groupthink and Cascade Effects}

While policy crowdsourcing might be seen as a means to increase the diversity of proposals placed before a legislative body, the crowdsourcing process itself may be subject to pressures that limit the expression of new and diverse ideas. Moss and Coleman (2013) warn that "low-threshold" political crowdsourcing that requires minimal activity and commitment presents a risk "of falling prey to unreflective groupthink, often shaped by the dominant prejudices of agenda-setting mass media" (p. 415). The term "groupthink" is used in political science to refer to the possibility that members of a deliberative group may feel pressure to self-censor their opinions in favor of a perceived group consensus. In the area policy of crowdsourcing, groupthink may manifest as cascade effects. Informational cascades occur when individuals disregard their own information to follow the behaviors of preceding individuals (Bikhchandani, Hirshleifer \& Welch, 1992; Sunstein, 2006). Such cascade effects have been observed in many online deliberative processes, including sharing on social news aggregation sites (Lerman \& Ghosh, 2010), participating in conversations in online political discussion forums (Velasquez, 2012), and engaging in online reviews and ratings (Moe \& Trusov, 2011).

\subsection{Participation Theatre}

In 2009, the Obama Administration coordinated several "online town halls" to allow citizens to pose questions directly to the president regarding issues such as health care reform. Although questions from the public were solicited via platforms like YouTube, Facebook, and Twitter, and Obama said he would answer "some of the 'more popular' questions," the project had established no online system to determine which questions were actually most important to the participants (Sifry, 2010, p. 120). Obama's staffers actually selected the questions for responses, which resulted in "an event that was less spontaneous and less town-hall-like than if all the questions had come from citizens live at the event using no technology at all" (p. 120). Sifry characterized this as "participation theatre." Grönlund (2011) argues "technology is a mallable [sic] medium able to serve many types of participation, including bogus types designed to in fact prohibit real participation" (p. 28). A reality check is necessary to ensure that eParticipation schemes are not just "window-dressing" or "politically correct electronic tools" that obscure or hinder real participation (Grönlund, 2011, p. 36). There is particular risk in policy crowdsourcing that participatory processes can backfire and increase public dissatisfaction. Irvin and Stansbury (2004) argue that if citizens expect that their participation is being taken seriously, but find that their decisions are "ignored or merely taken under advisement" (p. 59), then resentment may result. 


\subsection{Empowering Mischief and Abuse}

The power of policy crowdsourcing platforms to amplify individual voices, combined with limited personal accountability (or perceptions thereof) has led to major challenges for past initiatives. Providing an openly-accessible platform for citizen engagement may sometimes be seen as an invitation to mischief and even abuse. In 2010, the (US) Republican National Committee launched a web initiative titled America Speaking Out in a bid to engage their constituencies in developing the party's policy platform. (Then) House Minority Leader John Boehner stated, "I would expect the ideas that come out of this Web site and the involvement of our members will lead to ideas that we can attempt to implement today" (quoted in Milbank, 2010). Unfortunately for the Republicans, the site became a platform for (hopefully) insincere proposals, some silly -- "America needs a crack team of genetically engineered velociraptors who constantly patrol the skies in robot spyplanes" (McGlynn, 2010) - and some more vicious “Don't let the illegals run out of Arizona and hide... I think that we should do something to identify them in case they try to come back over. Like maybe tattoo a big scarlet 'I' on their chests -- for 'illegal'!!!" (Milbank, 2010). Moss and Coleman (2013) report on similar issues arising with a UK initiative called the Spending Challenge. Singer (2010) dryly noted that this site hosted citizen-submitted immigration policy proposals that fell into two categories: "racist ranting written entirely in lower case" and "RACIST RANTING WRITTEN ENTIRELY IN CAPITALS" (n.p.). In both cases, the sites were quickly shut down and then restarted: either with all the ideas deleted and a new, less open and transparent moderation system in place (America Speaking Out) or with the interactive features removed completely (Spending Challenge).

Avoiding these pitfalls should be a goal of all policy crowdsourcing initiatives. Aitamurto, Landemore, Lee \& Goel (2013) suggest that at least some of these challenges can be met when policymaking institutions can offer a "plausible promise" that participation in the initiative will have meaningful outcomes. Further, effective initiatives may provide civic benefits beyond the specific policy discussions at hand by enabling learning moments among participants (Aitamurto et al., 2013) and promoting deliberative reflection (Moss \& Coleman, 2013).

\section{Democratic Reason and Autonomous Citizenship}

The current climate for digital civic participation has evolved over decades of interactions among different stakeholders, and takes a wide range of forms. The terminology in this area remains fluid across different communities of practice and scholarship. While "automated governance" remains a worrying specter for some, technologies that impact and hopefully improve citizens' lives increasingly intersect with social and political domains. I suggest that two concepts can aid in understanding the strengths of policy crowdsourcing projects, and of Better Reykjavik in particular. Landemore (2012) uses the term "democratic reason" to describe the collective political intelligence of a population, and interprets democratic processes as a means to achieve the best political outcomes for those citizens.

Two factors underlie the democratic decision-making process, according to Landemore (2012): democratic deliberation and majority rule. Democratic deliberation is a problem-solving process that allows groups of individuals to come to reasonable or fair conclusions regarding issues of collective concern (c.f. Habermas, 1994). Majority rule, Landemore argues, is an efficient way to choose among 
multiple options. If the options are also generated fairly (perhaps via a deliberative process) then majority rule is also a fair way for a collective to select the "right" option ("where the 'right' one is simply that which is better than the other options," p. 265). She argues that cognitive diversity, or the plurality of information and worldviews within a group, plays a primary role in characterizing ethical and successful democratic systems. More specifically, she argues "the average mistake of the group will be less than the average mistake of a randomly selected voter." (p. 270). Maximal inclusion of participants and perspectives should be a goal of democratic systems, Landemore suggests, because the cognitive diversity of a larger group will be greater than that of a smaller group.

The value of maximal inclusivity in democratic processes holds across both direct and representative systems. Landemore (2012) notes, however, that deliberation processes have limits on their effective size, that "[i]n practice, past a certain numerical threshold, deliberation turns into a chaotic mess," (p. 262) necessitating the implementation of representational institutions. One of the purported advantages of digital political structures is the opportunity to increase the level of this threshold, by implementing system design that keeps this "chaos" at bay across ever-larger deliberative bodies.

If Landemore provides a compelling justification for the value of large and diverse deliberative systems, Coleman (2008) helps characterize the different types of online spaces where this interaction might occur. In his study of online civic youth cultures, Coleman (2008) argues for an approach to promoting online civic participation he terms "autonomous citizenship." He suggests that the use of information and communication technologies (ICTs) to promote civic engagement is not a new practice, noting the $19^{\text {th }}$ century Italian nationalism project made use of the printing press and the circulation of patriotic songs. Governments' efforts in this area are always subject to some suspicion that they are self-serving, that the government's actual goal "is to encourage beliefs and actions consistent with its own values and interests, while marginalizing dissenting voices" (p 190). eParticipation efforts are often seen to either be promoting either a "managed" style of engagement or an "autonomous" style of engagement. "Managed" initiatives tend to emerge from governments themselves, and emphasize the citizens' obligations or duties to the society (and government). The "autonomous" style of engagement can often be seen in initiatives that emerge from civil society, and often highlight citizens' independence and even resistance to the government.

In a similar formulation, Kersting (2013) defines the type of spaces where citizens may enact democratic processes as either "invited spaces" or "invented spaces." Invited spaces, such as "referendums, round tables, or forums" (p. 271) are typically managed by formal institutions such as governments or political parties. In contrast, "invented spaces" emerge from civil society as a counterweight to existing structures, enabling "new forms of protest and participation" (p. 271). Kersting argues that while purely online invented spaces may fail to solve democratic deficits, there is potential in "blended" initiatives that are designed with offline outcomes in mind. Coleman (2008) likewise concludes that a "productive convergence" (p. 201) of the managed and the autonomous is possible. If a government is truly committed to promoting eParticipation, Coleman suggests several principles it should adhere to in creating inclusive digital spaces for youth. When these principles 
are lightly edited (removing the word "young"), it becomes readily apparent that these are reasonable principles for any eParticipation initiative:

"1. Government is willing to fund, but not directly manage or interfere with, common online spaces in which [...] people are free to express themselves as citizens, and about the terms of citizenship.

2. Online democratic spaces [...] shall include horizontal channels of interaction, through which networks and collective associations can be formed, as well as vertical channels, providing dialogical links to various institutions that have power and authority over them.

3. It is up to [...] people to set the terms of their own political debate, without any external censorship.

4. E-citizenship involves both free expression and consequential political engagement. [P]eople are not to be expected to participate unless the scope and terms of their influence is explicitly outlined.

5. Among other aspects of e-citizenship, opportunities and resources will be provided to ensure that [...] people encounter others with whom they might disagree strongly, within various kinds of deliberative settings.

6. [P] eople are encouraged to mobilize online to counter social injustices and broaden the political agenda in any way that they see fit." (Coleman, 2008, p. 202-203)

Given this theoretical framework that suggests (1) the context through which effective democratic functions most readily occur and (2) the structure of digital spaces in which citizens can be most productively engaged, the Better Reykjavik initiative provides a novel and instructive case study in eParticipation. Better Reykjavik is a website that allows citizens to submit policy proposals to the municipal government. These ideas are publically accessible, and may be debated by participants either by submitting "comments" to a threaded discussion connected to each idea, or by submitting a specific "point" that either supports or opposes the proposal. "Points" are ranked by their perceived helpfulness, which is the aggregate response of other users to the question, "Is this helpful? Yes | No." Participants are also encouraged to make a simple vote on each proposal support or oppose. Over time, a body of proposals emerges, each idea refined by debate and competing "points," with the aggregate list ordered by the number of votes it has received. On the final business day of each month, the top ideas are automatically added to the next meeting agenda of the appropriate standing committee of the municipal government. As of July 2015, over 630 proposals have received formal consideration by the city, and 501 have been implemented (or are in the process of implementation) since the site launched in 2010 ("Top Ideas," 2014) -making it, perhaps, one of the most objectively "successful" policy crowdsourcing projects.

Better Reykjavik is receiving increasing attention from scholars within and outside Iceland. Lackaff and Grímsson (2011) provide an early historical and technical overview of the initiative. In their master's theses, Tiemann (2012) and Eiríksdóttir (2013) each focus on citizen perceptions of Better Reykjavik, drawing primarily on ethnographic data collected from users. In their comparative case study of eParticipation policy in Sweden, Estonia, and Iceland, Åström, Jonsson, Hinsberg, \& Karlsson (2013) highlight the "important differences" of the Reykjavik initiative: First, that the grassroots, independent character of the system is emphasized, and that the political system took the design of the technical system into consideration (rather than the reverse); second, that the 
government resolved to address a number of crowdsourced ideas each month without setting a minimum threshold of idea signatories; and third, that the system offers citizens "more opportunities to contest, refine, or combine one another's ideas and arguments than is usual in epetition systems" (p. 39).

Three distinct contexts are key to understanding the development and ongoing operation of the Better Reykjavik site: (1) The sociopolitical impacts of Iceland's economic crisis, (2) the rise of a new political party, (3) the development of the open-source "eParticipation" technical ecosystem. The following section examines the initiative as it is situated among these contexts.

\section{Better Reykjavik}

As of summer 2015 the City of Reykjavik's website describes the Better Reykjavik project as follows:

Better Reykjavik is a online consultation website where city residents have the opportunity to put forward their ideas on issues related to services and operations of the City. The forum is open to all opinions and participation that accords to the Terms of Use.

Registered users participate in this consultation system by presenting ideas, viewing others' ideas and arguments, stating their opinions, and giving specific ideas and arguments weight by voting for or against them.

When the user adds an idea to Better Reykjavik, it becomes the property of the commons using an adapted version of a Creative Commons license. The City of Reykjavik reserves the right to use the ideas presented in Better Reykjavik. However, it is not possible to formally review all submitted ideas.

The City of Reykjavik is committed to submitting the top five ideas (those receiving the highest vote of support) on the Better Reykjavik site each month for formal consideration by a City advisory board. In addition, the top idea in each category will be submitted for consideration by the respective Advisory Board (tourism, construction, leisure and recreation, sports, human rights, culture and the arts, education, transportation, planning, governance, environment, welfare, miscellaneous). At 12:00 on the last business day of each month, the top five ideas on Better Reykjavik and the top concept in each category receive a special status, and become ineligible for further voting. These ideas will be considered by an Advisory Board in person as soon as possible, ideally within a month. Expert Councils can potentially result in a longer time elapses before the formal review process. Other ideas that are not taken into consideration by the City of Reykjavik, however, remain open to dialogue with users Better Reykjavik.

Ideas that receive less support are intended to give advice to the elected officials and city managers.

Ideas that enter the formal City consideration process are presented in the name of Better Reykjavik as a crowd-sourced idea.

$[\ldots]$

It is expected that the Better Reykjavik will be developed in such a way that it can become a platform for electronic surveys or consultation of various kinds, such as strategic planning and prioritization of resources. A viable option is also in electronic referendums on specific matters, such as an electronic identification. 
The Citizens Foundation runs this site in cooperation with the City of Reykjavik.

\section{Enjoy. ${ }^{1}$}

Since October 2011, the City of Reykjavik has thus committed itself to having over one dozen ideas added to its meeting rosters each month: the five overall highest-voted, plus the top voted ideas in each category which corresponds to a specific city committee (e.g., transportation, sports, education). What would lead a city to invite this level of direct participation in city governance? For Reykjavik, much of the answer can be found in the impacts of an economic crisis of previously unimaginable proportions.

\subsection{Crisis and Iterative Innovation}

Iceland, an island nation of approximately 315,000 citizens, rocketed to the top of the world's development indices in the last quarter of the twentieth century. In 2008, however, three of its banks collapsed, sending the national economy into a tailspin and heralding the global recession. The impacts of the kreppa (crisis) were immediate and profound. The year 2009 witnessed an 18\% drop in per capita income (Valdimarsson, 2010) and the average real pay of Icelanders fell by as much as $28.7 \%$ (Magnusson, 2010). The population of Iceland declined by about $1 \%$ in 2009, with net emigration of 4,835 individuals (Statistics Iceland, 2010). In April 2010, the so-called Black Report was released. Commissioned by the Icelandic Parliament, the report detailed the results of an investigation into the causes of the financial collapse. Among other findings, it revealed that corrupt and criminal activity on the part of politicians and business moguls was significantly to blame (Special Investigation Commission, 2010). This did not come as news to most Icelanders, who had already identified cronyism as a primary factor in their nation's woes. An annual survey of Icelanders' trust in different institutions indicated that trust in Parliament, for example, plummeted from $40 \%$ in 2008 to $11 \%$ in 2011, and trust in most other institutions decreased as well (Jónsdóttir \& Árnason, 2014).

Given this context, it is not surprising that many initiatives that emerged in response to the kreppa originated among grassroots political activists, and not from official political institutions. One Saturday after the collapse of the banks, songwriter Hörð Torfason brought a microphone to a square outside of Parliament and invited fellow citizens to voice their confusion and frustration. Over a period of months, the weekly protests of the "Kitchenware Revolution" (named for the protesters' noisemakers of choice) grew to several thousand participants and culminated in the resignation of Prime Minister Geir Haarde in January 2009.

This grassroots protest context was supported by several projects and initiatives that brought political and policy discussions online. The weekly protests outside the Parliament building, for example, were initially spontaneous and later coordinated via Facebook. When clashes between protesters and police threatened to become violent, a Facebook campaign led to protesters wearing the color orange to indicate their intention to remain peaceful. Some activists, however, channeled their frustration into not only coordinating action online, but into building new platforms for

\footnotetext{
${ }^{1}$ English translation of http://reykjavik.is/betri-reykjavik-0, courtesy Gunnar Grímsson.
} 
political engagement. The development of bottom-up, grassroots approaches to online politics represents an interesting and novel development, showing how a fast, open, iterative technical development process can lead to social and political impact.

In 2008, Icelandic web developers Róbert Bjarnason and Gunnar Grímsson began developing an online platform for the discussion of policy ideas. They wanted to utilize their skills and experience to contribute to solutions for the situation in Iceland, and hoped to facilitate better communication between policy-makers and citizens. The Shadow Parliament (Skuggaping) website (http://skuggathing.is, now defunct), launched in 2009, was the first outcome of this initiative. This site allowed users to track debates in parliament, discuss agendas, and even offer their own amendments to bills. Although these activities were not directly connected to the functioning of the real Parliament, the intent was to increase awareness and transparency of official discussions among citizens. This project was developed as an open-source initiative, and Bjarnason and Grímsson named their new codebase Open Direct Democracy.

In a parallel development in January 2009, entrepreneur Guðjón Már Guðjónsson founded a group he called the Ministry of Ideas (Hugmyndaráduneytið). The Ministry began as a weekly meeting for entrepreneurs, and provided opportunities for networking and professional development. Within a few months of hosting increasingly popular meetings, the Ministry's organizers realized that their goals could be broader than just promoting new business, and that they could apply their interest in innovation to the broader sociopolitical problems facing their country. To help define these new goals and a new agenda, the Ministry began organizing a multimodal "envisioning" event, which would ultimately bring 1,500 Icelanders together face-to-face in a National Assembly (Pjófundar). Prior to the Assembly, Bjarnason and Grímsson launched a new Ministry of Ideas website to promote discussions of innovative new ideas (http://www.hugmyndaraduneytid.is, domain how hosts a Tumblr blog). Like the Shadow Parliament site, the Ministry website provided a platform for the discussion of ideas related to the future of Iceland, but more closely tailored to the interests of the creative entrepreneur classes. Rather than using Open Direct Democracy to build this new site, Bjarnason and Grímsson came across another open-source codebase called White House 2 which was being used to run a "game" or "simulation" of crowdsourced American presidency. White House 2 had features designed to counter the risks of wide-scale crowdsourcing project, such a points system that rewarded positive contributions ("shamelessly stolen from massively multiplayer online games like world of warcraft") (Gilliam, 2009).

After deploying the platform for the Ministry of Ideas and finding an ideologically-compatible agenda in the White House 2 codebase, the Icelandic team decided to merge the Open Direct Democracy and White House 2 code into a new platform for the next version of the Shadow Parliament site in February 2010: Open Active Democracy (Opna lýðræðiskerfið, http://github.com/rbjarnason/open-activeDemocracy). This new platform enabled the public to not only comment on and "amend" legislation, but to propose and deliberate over its own policy ideas. At its peak, the Shadow Parliament site had over two thousand registered users, although a much smaller number was active at any given time ("Hittu áhrifamesta fólkið hjá Skuggaping," 2011). 
Where the Shadow Parliament platform was focused solely on national politics, Bjarnason and Grímsson saw broader potential for this open innovation approach. They developed a site focused on innovation for city-level policy focus in May 2010. The Shadow City site (http:/ /skuggaborg.is) opened shortly before the Reykjavík municipal elections. Each of the eight political parties vying for seats on the council was provided with a "branded" section of the site to use to connect with potential voters and learn about voters' political priorities. Few of the parties made use of the site, with the major exception of a new party calling itself the "Best Party." Actor and comedian Jón Gnarr had founded the party a few months earlier, making outlandish campaign promises that satirized the entire political process (the party promised voters a Disneyland, a polar bear, and free towels, among other things). When it became apparent that Gnarr's joke party was actually leading in most of the polls, the party saw the Shadow City as a way to connect with potential voters and develop a more realistic party platform that reflected constituents' interests. As the election drew near, the Best Party section of the site (and to a lesser extent, the Social Democrat section) saw significant activity, as over 1,300 citizens participated.

\subsection{The Best Party Solution to the Middleman Paradox}

On May 29, 2010 the Best Party defeated the incumbent Independence Party in the city council election, and subsequently entered into coalition talks with the Social Democrats. Best Party officials, having been impressed with the system and its possibilities, asked Bjarnason and Grímsson to create a website to solicit citizen opinion for the city council coalition platform. Gnarr noted,

"As I was getting very into city politics and planning, I was quite active [on Shadow City]. Most of us were quite active there to see what was the hottest topic and what people wanted. We decided we are all very interested in possibilities to make direct democracy work, and we saw this as a brilliant solution." 2

\footnotetext{
${ }^{2}$ Gnarr interview, January 2012.
} 
Figure 1. Example of idea on Better Reykjavik, with "pro" and "con" points below.

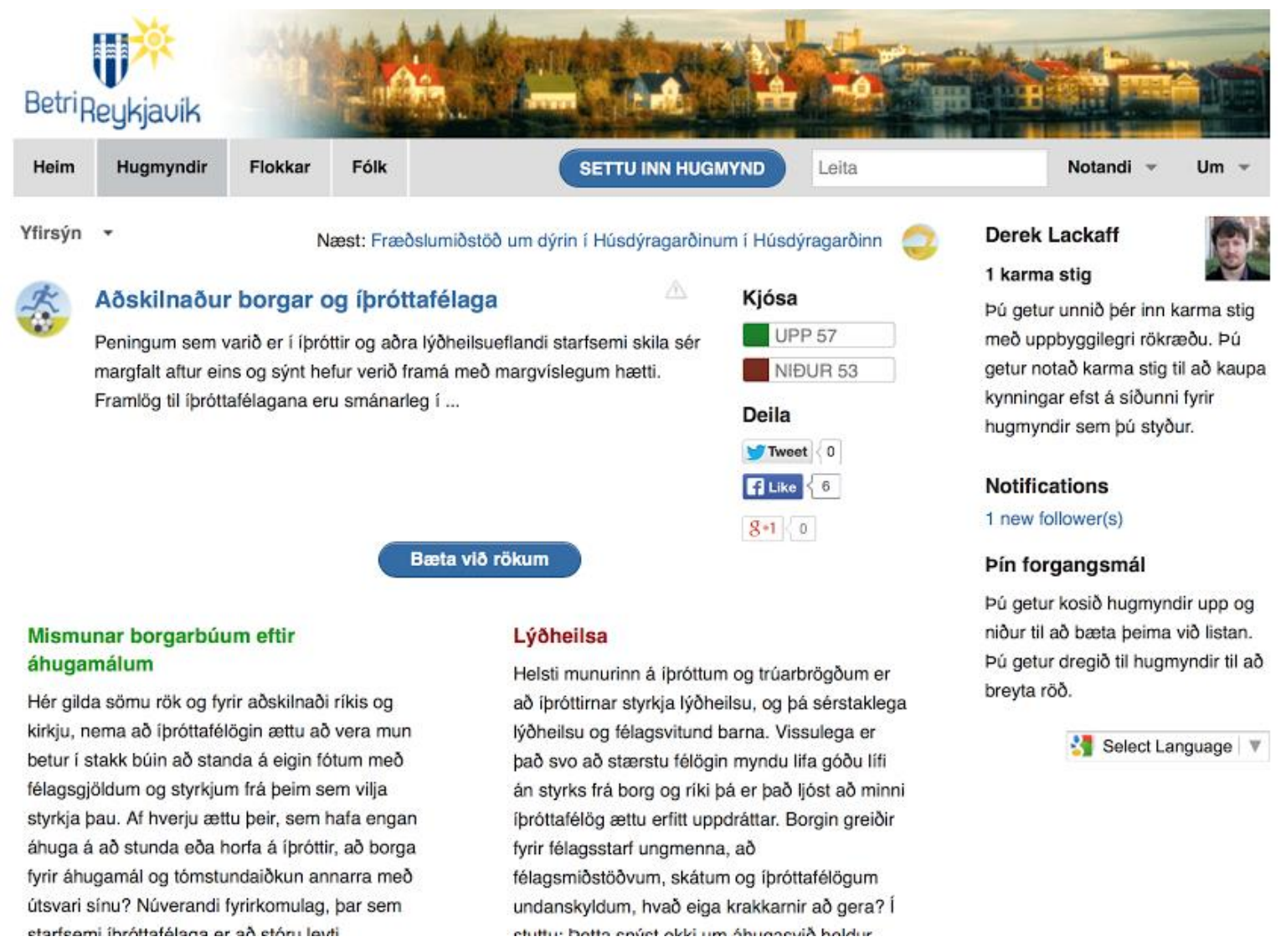

Bjarnason and Grímsson opened a new section of the Shadow City website called Better Reykjavík (Betri Reykjavík), and the coalition partners encouraged citizens to use the site to share their priorities for the new government (Figure 1 provides a screenshot). Soon over 5,000 users were participating on the site - an impressive figure in a municipality where a total of 56,897 votes were cast. Within months, several of the highest-rated ideas from the Better Reykjavík site had been placed at the top of the policy agenda listed on the Best Party website ("Besti Flokkurinn", 2010), and many were soon implemented (Fyrir gangandi og hjólandi folk" 2010; "Nætursund í Laugardalslaug", 2010).

\subsubsection{Direct Democracy}

In stark contrast to the Austrian parliamentarians interviewed by Mahrer and Krimmer (2005), the new Reykjavik administration openly and broadly endorsed the development of direct democratic institutions. In this case, the momentum of the new city council was with the members of the Best Party, who were truly outsiders to political power, and who seemed to have little personal interest in consolidating their influence - effectively solving the "middleman paradox." The new administration remained excited about the potential of Better Reykjavik to remain a key component of governance. Gnarr, now mayor, enthused about the potential of technologies to help solve his city's civic challenges, particularly those that enabled more direct democracy: "I think the best democracy from now on will be direct democracy. We have tried all kinds of democracy, but we have never really tried direct democracy. The timing is right, because we have the technology to 
make it more user-friendly and simple" ${ }^{3}$ He also suggests that Reykjavik's relatively small size contributes to its potential: "We are a miniature big city. We are only 100,000 people. It is so easy to make a test tube for direct democracy here."4 Eggert Ólafsson, manager of the City's IT department, understands Better Reykavik as a clear example of direct democracy in practice:

"I think [Better Reykjavik] is a very interesting experiment on direct democracy, or what the United Nations have defined as eParticipation. Better Reykjavik is definitely supporting that kind of direct democracy. The UN have defined eParticipation in three parts - first, information given by the government to enable citizens to make their own decisions or meaning about things, second consultation with the citizens, and third direct decisionmaking. Better Reykjavik, as it is now, almost supports all three parts."5

Dagur B. Eggertsson, then a Social Democrat councilperson, concurred, stating, "[It is my opinion] that power comes from beneath, from the people, to those who govern, and we don't have too many tools that reflect that in decision-making. So I'm very excited to see how this will develop" ${ }^{6}$ Eggertsson sees value in Better Reykjavik for deliberative democracy, as well as direct democracy. "[Better Reykjavik] is a new tool both in direct democracy and in the process, in deliberative democracy, because ideas are not just aired or shouted, but debated and discussed, liked and disliked."7

The city soon formed a steering committee to explore how the crowdsourcing process of Better Reykjavik could be more formally adopted as a channel for citizen engagement in policymaking. Hreinn Hreinnson, the City's web director, chaired the committee of several city administrators and politicians. Hreinnson notes that the politicians - many of whom were new to city governance, and some of whom (like Jón Gnarr) touted this as a political strength -- may not have initially realized that this would be a relatively complicated process. ${ }^{8}$

Over the course of a year, this steering committee devised a plan that did not require any legal policy changes. Technical management of the project would remain in the hands of Bjarnason and Grímsson, rather than transferring to the city. Hreinnson suggests, "It would be impossible for us to run this project within the city, because of all the laws regarding administration and how we should handle complaints and things like that." 9 A manager from the city would be assigned to the project, with the charge of collecting the top ideas and distributing them to the relevant administrative committees. This project manager would convene a monthly meeting, inviting representatives from each standing city committee, and present and explain the ideas to the representatives. The representatives in attendance would then take the ideas and ensure they were placed on the meeting agendas of their respective committees.

\footnotetext{
${ }^{3}$ Ibid.

${ }^{4}$ Gnarr interview, 2012.

${ }^{5}$ Olafssson interview, January 2012.

${ }^{6}$ Eggertsson interview, January 2012.

${ }^{7}$ Eggertsson interview, January 2012.

${ }^{8}$ Hreinsson interview, August 2014.

${ }^{9}$ Ibid.
} 
In December of 2010, Bjarnason and Grímsson founded a non-profit organization called Íbúar SES ("Citizens Foundation") and moved control of their democratic projects to that organization. In October 2011, the City of Reykjavik signed a contract with the Citizens Foundation to provision the Better Reykjavik platform for crowdsourcing municipal policy ideas.

\subsection{A Democratic Agenda: The City's Goals}

The Best Party was elected on a platform that promised a radically new approach to politics, and thus had a broad mandate for experimentation. The City had multiple goals in implementing the Better Reykjavik site, including the restoration of civic trust, expanding participation in governance, and promoting a deeper understanding of city governance among residents.

\subsubsection{Trust}

A lack of trust from citizens was a primary challenge for the new administration. Trust in many institutions in Iceland - the Parliament, the judiciary, the banks, etc. -- fell precipitously during the crisis. According to an annual survey conducted by Capacent Gallup (Jónsdóttir \& Árnason, 2014), while trust in the Reykjavik City Council actually rose from 2008-2010, it rose from just $9 \%$ to $22 \%$ - grim figures by any measure. Both politicians and City administrators recognized this issue. Hreinsson put it baldly: "In Iceland, there is a real distrust going on. People don't trust politics or politicians." 10 Eggertsson concurred, noting that "the underlying problem here is one of distrust of politicians and of other institutions." 11

Better Reykjavik was clearly understood to be a tool that could help restore public trust, but that also posed the risk of exacerbating mistrust if not implemented appropriately. As previously mentioned, insincere public engagement initiatives can backfire (Irvin and Stansbury, 2004) leaving governments in an even worse position than they were before. Eggertsson argues:

"We have to deliver on the promise we have given by using Better Reykjavik, because if we don't do that, we are widening the gap [in public trust]. It can't be just for fun, it has to be to take real decisions, and that is the promise we want to deliver on." 12

Eva Einarsdóttir, a Best Party councilperson, suggested that Better Reykjavik could help cultivate a deeper trust in democratic institutions among the youth. One of the first ideas to be implemented via the Better Reykjavik process was submitted by a 9-year-old student who wanted to see more school field trips. "If children are participating," Einarsdóttir argues, "it must give them a newfound trust in the local government, that they can have something to say in the community. Maybe [once they see that] they can actually do something, they [won't] take democracy for granted."13

\footnotetext{
10 Hreinsson interview, January 2012.

11 Eggertsson interview, January 2012.

12 Ibid.

13 Einarsdóttir interview, January 2012.
} 


\subsubsection{Participation and Inclusivity}

If you build it, will they come? Without buy-in from participants, even the most well intentioned eParticipation initiatives will fail. A third goal of the new city government was to promote deeper and broader participation in city governance. In his memoir, Gnarr (2014) extolled the virtues of digital interaction with the city:

"Instead of spending two hours in some stuffy office down in the city, drinking vending-machine coffee and listening to vacuous anecdotes about some employee's private life, you can site comfortably at home, in peace and quiet, at your computer, in your underwear if you feel like it."

The City also hoped that the direct connection of ideas submitted to Better Reykjavik to the machinery of city policymaking would encourage participation. "It creates a clear channel into the nuts and bolts of the city of Reykjavik. We didn't want it to just be an open webpage where you could discuss the city," noted Eggertsson. "[If] the citizens can see that they can influence the city government, I think this will encourage them to be more active in this local society, in Reykjavik." Hreinsson argues that Better Reykjavik can change the way people think about the policy-making process. "Tools like [Better Reykjavik] can help, because when you ask people in Iceland if they are interested in politics, most of them say no, we are not. But if you ask people questions on specific issues, you find a lot of interest around."14

Eggertsson also focused on the potential of the site to increase the breadth of participation. "We hope to both get the views of a larger number, different groups, more young people, and to have more of a constant dialogue, more informal and open."15 As Landemore (2011) argues, this diversity of opinion is a key prerequisite for effective democratic systems.

\subsubsection{Civic Understanding}

Finally, several City leaders suggested that Better Reykjavik could potentially serve an educational function and help residents understand the "big picture" of city governance. When we spoke in 2012, Hreinnsson suggested, "I think it gives them more sense of power over the city as a whole. It is easy to use; a lot of people are using it. It helps people to understand how the city actually works, and how decisions are made by the specialist committees." During our second interview in 2014, his opinion was more equivocal: "I'm not sure if people's understanding of city administration has changed. One conclusion is that people just aren't that interested in how government administration works. I totally understood that. People only want to put in some ideas, get some answers, and that is that."

Einarsdóttir found that many citizens were surprised with the outcome of their participation in the policy crowdsourcing process. The opportunity to see their ideas and opinions in context, among hundreds of competing positions, might help engender empathy among residents for the challenges

\footnotetext{
14 Hreinsson interview, January 2012.

15 Eggertsson interview, January 2012.
} 
of managing a representative government. "As a councilor, I have to think about the big picture, so I think it is good for people to see why we have to say no to some ideas, because we get a lot of ideas." She further noted, "we have people come in with great ideas, and they are very surprised when we cannot implement them. Visiting the website might open your eyes [to the government's perspective]."16

\subsection{Adoption by 2014 Government}

In May 2014, a municipal election ushered in a new government. Jón Gnarr decided not to seek a second term in government, and his Best Party was disbanded. Several of his former colleagues created a new party, Bright Future, which stood in the election. In the end, the Social Democrats came out on top, winning a small plurality with five of the 15 seats. The Social Democrats formed a governing coalition with the two members of Bright Future, two members of the Left-Greens, and the single member of the Pirate Party. Social Democrat Dagur B. Eggertsson was appointed the new mayor. Eggertsson remains enthusiastic about the Better Reykjavik project, but hopes to develop strategies to improve the initiative. "I think that the new administration is very positive and eager to develop BR further, but we want to know more about what went well."17

When the new coalition released its policy agenda statement, the first section document listed "transparency and increased residential democracy" as a primary goal of the new government (Samstarfssáttmáli, 2014). Reflecting the presence of the Pirate Party in the coalition, a new standing committee - the "Administration and Democracy Council" -- was formed. The committee, headed by Pirate councilperson Halldór Auðar Svansson, is charged with tasks such as improving access to information, increasing the participation of citizens in decision-making, and promoting the use of open-source and free software. Better Reykjavik found a new administrative home under the auspices of this committee. The committee is tasked with conducting a study of Better Reykjavik and making suggestions for the next steps in electronic participatory democracy. This represents a further formalization of Better Reykjavik within the City's administration, as the project now has a clear place in the City's overall organizational structure.

\subsection{Better Reykjavik: Autonomous Policycrafting and the "New Normal"}

In many ways, things are looking up in Iceland (Bowers, 2013). A program of increased taxes and cuts to public spending led to an orderly exit from an International Monetary Fund bailout program in 2011. The economy began growing again in 2011, and unemployment fell back to nearly $5 \%$, far lower than many other places in the developed world. In 2013, Icelandic voters welcomed back the center-right Independence Party and Progressive Party to lead Parliament - the same parties that presided over the financial deregulation that caused the crisis just a few years earlier. Trust in the Reykjavik City Council had declined from 22\% in February 2010 to 15\% in February 2012, but increased to 31\% by February 2014 (Jónsdóttir \& Árnason, 2014).

\footnotetext{
16 Einarsdóttir interview, January 2012.

17 Eggertsson interview, August 2014.
} 
As the municipal elections of 2014 approached, Reykjavik's political, economic, and cultural climate had clearly shifted from its crisis state of 2010. Just fewer than $63 \%$ of eligible voters participated in the May 2014 election. When asked if this apparent political disinterest reflected Reykjavik political life getting back to normal in light of an ostensibly improving economic situation, Eggertsson replied: "No, normal was vast participation in all elections. So this is back to some new normal, where big groups are not participating, especially young people."18 Indeed, this voter turnout was the lowest in Reykjavik since Iceland became independent in 1944.

Better Reykjavik's web analytics support the City's contention that the platform has become part of the city's policy landscape. Between October 2011 and September 2014, 11,390 users registered to participate on the site, 1,959 ideas were submitted, 3,339 points for and against specific ideas were posted, and 2,706 comments informed the debate about these ideas. Over 500 ideas were submitted in the first five weeks following the site's official launch. Site activity spikes in response to specific campaigns (such as the City's participatory budgeting initiative, Better Neighborhoods [Betri Hverfi], which is run through the Better Reykjavik platform), but generally generates a modest amount of activity per week, with a few to a few dozen ideas posted. We suggest that the continued operation, and success, of Better Reykjavik can be understood across two domains: process legitimacy and political normalization.

\subsubsection{Process Legitimacy}

From the perspective of the City, Better Reykjavik offers a legitimate promise of access to political power to citizens. The evidence suggests that there was a good-faith effort to make the project work from the very beginning. City administrators like Hreinnsson attempted to make a clear case to the new government that legitimacy was key:

"We were very focused on trying to explain to the new administration in 2010 that if they were going to go with the Better Reykjavik project, it would not be a good idea to do a new experiment, but to institutionalize the project, to make it a formal part of the administration. It was clear at the beginning -- no one wanted to doubt that we were doing something for keeps."19

This attempt to legitimize the project seems to have reaped rewards for the government. "I think Better Reykjavik is one of the reasons that the City of Reykjavik administration is quite stable," argues Hreinsson. "We don't get criticism like might be normal. Take parliament, for example. Trust in parliament is less than 10 or something like that. Trust in city government is much higher. I would describe it as stable and calm, and people and general are trusting the city administration." 20

Hreinsson relates that the City initially received several complains from participants when the City began its formal consideration of crowdsourced ideas.

${ }^{18}$ Eggertsson interview, September 2014.

${ }^{19}$ Hreinsson interview, August 2014.

${ }^{20}$ Ibid. 
"The administration tended to answer very vaguely, unclear answers, answers like 'we are going to look into this,' and we were actually aiming at getting answers like 'yes' or 'no,' [...] That is probably going much better now. We are getting clearer answers now from the committees. It's not a revolution, but it's a step forward at least." 21

Eggertsson relates that the city government made several decisions in an attempt to promote the legitimacy of the process. ${ }^{22}$ For example, the City decided that politicians and administrators would not directly participate in discussions that took place on the site (adding points for or against ideas, etc.) but would wait to address the ideas after then had been submitted to the committees.

The process of idea submission to the government was also depersonalized in an attempt to increase the legitimacy of the process. When ideas are presented to the committees, they are stripped of identifying information regarding their authors. Unnur Margrét Arnardóttir, who became the City's project manager for Better Reykjavik in 2014, explains why the ideas are submitted anonymously: "Because this is a crowdsourcing project there's no one person who is responsible for a certain idea, even though somebody first posted it." 23

Finally, the decision was made to accept ideas based on their priority, and no minimum threshold of votes was determined. This resulted in a steady stream of crowdsourced ideas percolating throughout the machinery of the city government that is responsive to any ebb and flow of site participation.

However, some of these decisions may need to be reconsidered in the future. Eggertsson suggested that the lack of City participation on the site during the voting phase might lead to missed opportunities to engage different opinions. "Without the deliberative part, it is [just] a voting system. Without the discussion, you can leave out deeper understandings of the issues or problems, on both sides. Also on the side of those who receive them in the committees." Likewise, the absence of a minimum threshold for votes leads to "weaker" ideas moving through the process. "It would strengthen both the legitimacy of the process, if people need to rally a bit to get their ideas on the table. Then I think more people would be involved, more people would participate, and more people would deliberate, etc." 24

The fact that ideas have no specific "champions" once they pass from Better Reykjavik to the city may also be problematic. Arnardóttir notes that the "ideas committee" (comprised of representatives from the different standing committees who discussed the Better Reykjavik ideas, and then added them to their respective meeting agendas) had actually stopped meeting, "because people stopped coming to the meetings. The meetings weren't adding much to the process." Arnardóttir now

\footnotetext{
21 Ibid.

22 Eggertsson interview, September 2014.

23 Arnardóttir interview, August 2014.

24 Eggertsson interview, September 2014.
} 
submits the top ideas to the committees via email. "We who are working in the administration sometimes think the ideas need a representative or speaker in some way." 25

\subsubsection{Normalization}

The City also perceives that Better Reykjavik has been largely normalized as a channel for citizen participation. Arnardóttir notes, "It's a well-known project. You meet people who will tell you stories about how they submitted an idea and something changed in their neighborhood." 26 Eggertsson likewise finds that Better Reykjavik has been normalized ("to a great extent") but sees a slightly different risk in the context of that normalization: "I think the danger is more that it will be both in practice and in the public mind connected to the 'active' part of society." If this is an accurate perception - that the initiative is amplifying those voices that are already engaged with and interested in city governance, rather than providing a venue for new ones and new ideas - it represents a significant strategic and practical challenge for the new government.

The fact that Better Reykjavik is operated in Icelandic (although the user interface can be navigated in several languages, almost all of the user-generated content is in Icelandic) also presents some unique challenges and benefits. A benefit, from the government's perspective, is that the Icelandic language serves as a powerful barrier to unintentional audiences who might engage to troll or have a laugh (such as those who joined America Speaking Out to mock Republican policy.) However, the language barrier may also prevent the participation of some of the more politically isolated populations in Iceland, such as immigrants and refugees. Eggertsson notes, "The weakness of such a tool (that is run in Icelandic) is that you don't get the marginalized groups that don't participate in the democratic process into this tool either." 27

When asked if Better Reykjavik had "partisan" associations (given the project's close ties to the Best Party, and now the Social Democrat, coalitions) that would make it politically difficult for a new government to continue it, Hreinnsson replied that it was a risk. "Nobody would stop the project unless they had something else -- another platform or another process, because it has been institutionalized. Nobody would go backwards, but they would probably do something else." 28 Arnardóttir concurs, noting that given their public critiques of the initiative, the current opposition parties might "have a hard time continuing with it, as is." 29

\section{Conclusion: Maintaining Momentum}

For many working within the City, there is currently a perception that the Better Reykjavik initiative has slowed down. Arnardóttir notes, "It is something that people take for granted in some ways [...]

\footnotetext{
25 Arnardóttir interview, August 2014.

26 Ibid.

27 Eggertsson interview, September 2014.

28 Hreinnsson interview, August 2014.

29 Arnardóttir interview, August 2014.
} 
It's there, and it's working properly, but it is not a high-flying project anymore." 30 The City is actively engaged in planing its agenda for Better Reykjavik over the next few years. The Mayor is particularly interested in expanding the engagement of groups who seem to still be outside the sphere of municipal civic engagement. "What surprised us was that we thought this tool would be more engaging for the youngest part of the population, for example, but it seemed to have engaged the more typical age group that is active in activism and political issues in general." 31

The City's core challenge with the Better Reykjavik initiative at this point is a lack of meaningful evaluation data. In our 2014 interview, Eggertsson suggested several questions he hopes will be answered by the evaluation to be conducted by the new Administration and Democracy Council:

- "to what extent is this a new channel for those who are already active and having their voice heard, and to what extent this tool engaged new groups and new voices that we weren't hearing before"

- "to what extent classically marginalized groups participated"

- "[how] to develop tools or venues to get the voices of people who are not voting into city government" 32

In many important ways, contemporary Iceland presents a highly specific cultural, social, and historical context for the development of participatory sociotechnical governance systems. This case study attempts to illuminate this context, but also to help explain why Better Reykjavik may provide insights for future projects. To return to Coleman's (2008) criteria for effective eCitizenship initiatives, several arguments can be made that the City government established Better Reykjavik as a functioning space for autonomous citizenship. First, the 2010 government recognized the value in the existing, grassroots-developed Shadow City platform, and chose to adapt itself to that platform. It funded development and committed itself to respecting the deliberative process of the platform, but declined to take full ownership and control of the initiative. Second, the platform itself allowed both horizontal interaction (citizens proposing, debating, and voting on proposals) and vertical interaction (prioritization of ideas in specific categories, and a connection to the city). Third, participants were invited to deliberate and discuss their ideas freely, with a Terms of Use supported by distributed community moderation of problem content, rather than top-down moderation or censorship. Fourth, the platform offers a direct and transparent connection to the formal policymaking process. Every vote and update on the site is public record, so participants can have a full understanding of how their participation is translated into public action - or not. Finally, the site encouraged broad participation, presenting a user and civic experience that generally improved as the scale increased. Although Reykjavik's context is unique, cases like Better Reykjavik suggest the potential for civic partnerships that promote political crowdsourcing and autonomous citizenship.

As Eggert Ólafsson, the city's IT manager notes: “This is an experiment, but it is also more than an experiment, because it is already a part of what is happening here in Reykjavik."

\footnotetext{
30 Ibid.

31 Eggertsson interview, September 2014.

32 Eggertsson interview, September 2014.
} 


\section{Author's Note on Icelandic Names}

Icelanders do not generally have family surnames, but generally have their father's first name as their last name (patronymic): "Thorvald Einarsson" is literally "Thorvald, son of Einar," and would be addressed in most contexts as just "Thorvald." In hope of presenting a more comprehensible narrative to readers in English, I intentionally (and inaccurately) refer to most individuals by their patronymics in this manuscript.

\section{References}

Aitamurto, T. (2013). Crowdsourcing for Democracy: New Era in Policy-Making. Parliament of Finland. Retrieved from http://cddrl.stanford.edu/news/3804/

Aitamurto, T., \& Landemore, H. (2013). Democratic Participation and Deliberation in Crowdsourced Legislative Processes: The Case of the Law on Off-Road Traffic in Finland. Presented at the Communities and Technologies: Workshop on Large-Scale Idea Management and Deliberation Systems.

Aitamurto, T., Landemore, H., Lee, D., \& Goel, A. (2013, October 30.). Seven lessons from the crowdsourced law reform in Finland. Retrieved from http://thegovlab.org/seven-lessons-from-the-crowdsourcedlaw-reform-in-finland/

Åström, J., Jonsson, M., Hinsberg, H., \& Karlsson, M. (2013). Case studies on e-participation policy: Sweden, Estonia and Iceland. Praxis Policy Center. Retrieved from http://www.divaportal.org/smash/record.jsf?pid=diva2:638808

Babington, C. (2010, June 20). New Republican Agenda, Or Lack Of One, Divides Party. Retrieved June 30, 2014, from http://www.huffingtonpost.com/2010/06/21/new-republican-agenda-or_n_618964.html

Bertot, J. C., Jaeger, P. T., \& Grimes, J. M. (2010). Crowd-sourcing transparency: ICTs, social media, and government transparency initiatives. In Proceedings of the 11th Annual International Digital Government Research Conference on Public Administration Online: Challenges and Opportunities (pp. 51-58). Digital Government Society of North America. Retrieved from http:/ / dl.acm.org/citation.cfm?id=1809874.1809887

Besti Flokkurinn. (n.d.). Retrieved September 22, 2014, from http:/ / bestiflokkurinn.is/

Betri Reykjavík. (n.d.). Retrieved July 28, 2014, from http://reykjavik.is/betri-reykjavik-0

Bikhchandani, S., Hirshleifer, D., \& Welch, I. (1992). A Theory of Fads, Fashion, Custom, and Cultural Change as Informational Cascades. Journal of Political Economy, 100(5), 992-1026.

Bowers, S. (2013, October 6). Iceland rises from the ashes of banking collapse. The Guardian. Retrieved from http://www.theguardian.com/world/2013/oct/06/iceland-financial-recovery-banking-collapse

Brabham, D. C. (2009). Crowdsourcing the Public Participation Process for Planning Projects. Planning Theory, 8(3), 242-262. doi:10.1177/1473095209104824

Brabham, D. C. (2012a). Motivations for Participation in a Crowdsourcing Application to Improve Public Engagement in Transit Planning. Journal of Applied Communication Research, 40(3), 307-328. doi:10.1080/00909882.2012.693940 
Brabham, D. C. (2012b). The effectiveness of crowdsourcing public participation in a planning context. First Monday, 17(12). doi:10.5210/fm.v17i12.4225

Brito, J. (2007). Hack, Mash \& Peer: Crowdsourcing Government Transparency. Retrieved from http://works.bepress.com/jerry_brito/1

Coleman, S. (1999). Cutting out the middleman: From virtual representation to digital deliberation. In B. N. Hague \& B. D. Loader (Eds.), Digital Democracy: Discourse and Decision Making in the Information Age. New York: Routledge.

Coleman, S. (2008). Doing IT for themselves: Management versus autonomy in youth e-citizenship. In W. L. Bennett (Ed.), Civic life online: Learning how digital media can engage youth (pp. 189-206). Cambridge, MA: MIT Press.

Coleman, S., \& Blumler, J. G. (2009). The Internet and Democratic Citizenship: Theory, Practice and Policy (1st ed.). Cambridge University Press.

Eiríksdóttir, S. (2013). Rættist draumurinn? Um virkni samráđsvefjarins Betri Reykjavík í ljósi íbúalýðræðis. Retrieved from http://skemman.is/item/view/1946/16407

Fyrir gangandi og hjólandi fólk. (2010, July 12). Visir.is. Retrieved from http://www.visir.is/fyrir-gangandiog-hjolandi-folk/article/2010583635150

Gilliam, J. (2009). Imagining White House 2.0. Retrieved September 20, 2014, from http://3dna3dna.nationbuilder.com/imagining_white_house_2_0

Gnarr, J. (2014). Gnarr: How I Became the Mayor of a Large City in Iceland and Changed the World. Brooklyn, NY: Melville House.

Grönlund, Å. (2011). Connecting eGovernment to Real Government - The Failure of the UN eParticipation Index. In M. Janssen, H. J. Scholl, M. A. Wimmer, \& Y. Tan (Eds.), Electronic Government (pp. 26-37). Springer Berlin Heidelberg. Retrieved from http:/ /link.springer.com/chapter/10.1007/978-3-642-22878$0 \_3$

Habermas, J. (1994). Three Normative Models of Democracy. Constellations, 1(1), 1-10. doi:10.1111/j.14678675.1994.tb00001.x

Hittu áhrifamesta fólkið hjá Skuggaping. (2011, December 13). Retrieved September 20, 2014, from http://web.archive.org/web/20111213224028/http://skuggathing.is/network

Irvin, R. A., \& Stansbury, J. (2004). Citizen Participation in Decision Making: Is It Worth the Effort? Public Administration Review, 64(1), 55-65. doi:10.1111/j.1540-6210.2004.00346.x

Jónsdóttir, S. D., \& Árnason, J. K. (2014). Djóðarpúlsfréttir: Traust til stofnana. Capacent Gallup. Retrieved from http://www.capacent.is/rannsoknir/thjodarpulsinn/nr/1806

Kersting, N. (2013). Online participation: from "invited" to "invented" spaces. International Journal of Electronic Governance, 6(4), 270-280. doi:10.1504/IJEG.2013.060650

Lackaff, D. \& Grímsson, G. (October, 2011). Shadow governments: An Icelandic experiment in participatory governance and social change. Paper presented at the annual conference of the International Studies Association-South, Elon University, Elon, North Carolina, USA. 
Landemore, H. (2012). Democratic Reason: Politics, Collective Intelligence, and the Rule of the Many. Princeton University Press.

Lerman, K., \& Ghosh, R. (2010). Information Contagion: An Empirical Study of the Spread of News on Digg and Twitter Social Networks. In Fourth International AAAI Conference on Weblogs and Social Media. Retrieved from http://www.aaai.org/ocs/index.php/ICWSM/ICWSM10/paper/view/1509

Levy, P. (1997). Collective Intelligence: Mankind's Emerging World in Cyberspace. (R. Bononno, Trans.) (1st edition.). New York: Plenum Trade.

Magnússon, H. S. (2010, May 25). What Are You Voting For, Reykjavík? Retrieved September 22, 2014, from http://grapevine.is/mag/feature/2010/05/25/feature-what-are-you-voting-for-reykjavik/

Mahrer, H., \& Krimmer, R. (2005). Towards the enhancement of e-democracy: identifying the notion of the "middleman paradox." Information Systems Journal, 15(1), 27-42. doi:10.1111/j.1365-2575.2005.00184.x

McGlynn, K. (2010, May 28). GOP Website Brings Out The Crazy: The Funniest Quotes From "America Speaking Out" (PICTURES). Retrieved September 16, 2014, from http://www.huffingtonpost.com/2010/05/28/gop-website-brings-out-th_n_591937.html

Milbank, D. (2010, May 26). Republicans' new Web site not exactly what they hoped it would be. The Washington Post. Retrieved from http://www.washingtonpost.com/wpdyn/content/article/2010/05/25/AR2010052504396.html

Moe, W. W., \& Trusov, M. (2011). The Value of Social Dynamics in Online Product Ratings Forums. Journal of Marketing Research, 48(3), 444-456. doi:10.1509/jmkr.48.3.444

Moss, G., \& Coleman, S. (2014). Deliberative Manoeuvres in the Digital Darkness: e-Democracy Policy in the UK. The British Journal of Politics \& International Relations, 16(3), 410-427. doi:10.1111/1467-856X.12004

Nætursund í Laugardalslaug. (2010, July 20). Mbl.is. Retrieved from http://www.mbl.is/frettir/innlent/2010/07/20/naetursund_i_laugardalslaug/ /

Sæbø, Ø., Rose, J., \& Skiftenes Flak, L. (2008). The shape of eParticipation: Characterizing an emerging research area. Government Information Quarterly, 25(3), 400-428. doi:10.1016/j.giq.2007.04.007

Samstarfssáttmáli: Við myndun meirihluta borgarstjórnar Reykjavikur 2014-2018. (2014). Retrieved from http://www.dv.is/media/attachments/samstarf.pdf

Schuler, D. (2001). Cultivating Society's Civic Intelligence: Patterns for a New "World Brain." Information, Communication \& Society, 4(2), 157-181. doi:10.1080/13691180122844

Sifry, M. (2010). "You Can Be the Eyes and Ears": Barack Obama and the Wisdom of Crowds. In D. Lathrop \& L. Ruma (Eds.), Open Government: Collaboration, Transparency, and Participation in Practice (pp. 115-122). Sebastopol, CA: O’Reilly Media.

Singer, C. (2010). Government's Spending Challenge website now offers you comedy gold. Retrieved from http:/ / liberalconspiracy.org/2010/07/14/governments-spending-challenge-website-now-offers-youcomedy-gold/ 
Special Investigation Commission. (2010). Report of the Special Investigation Commission, Executive Summary (English). Retrieved September 22, 2014, from http://www.rna.is/eldri-nefndir/addragandiog-orsakir-falls-islensku-bankanna-2008/skyrsla-nefndarinnar/english/

Statistics Iceland. (2010). Migration 2009 (No. 24/2010). Retrieved from http:/ / www.statice.is / ?PageID=444\&NewsID=5034

Sunstein, C. R. (2006). Deliberating Groups versus Prediction Markets (or Hayek's Challenge to Habermas). Episteme, 3(03), 192-213. doi:10.3366/epi.2006.3.3.192

Tiemann, J. (2013). Decision-Making in Digital Democracy. Accessing the Online Participation Tool Betri Reykjavik. (Unpublished MA thesis). Georg-August- Universität, Göttingen, Germany.

Top ideas. (2014). Retrieved August 1, 2014, from https:/ / betrireykjavik.is/ideas/top

Valdimarsson, O. R. (2010, March 9). Iceland Political Discord Grows Amid Election Demands (Update1). Retrieved from http://www.bloomberg.com/apps/news?pid=newsarchive\&sid=awFwtxYG0E90

Velasquez, A. (2012). Social media and online political discussion: The effect of cues and informational cascades on participation in online political communities. New Media \& Society, 14(8), 1286-1303. doi:10.1177/1461444812445877

Vicente, M. R., \& Novo, A. (2014). An empirical analysis of e-participation. The role of social networks and egovernment over citizens' online engagement. Government Information Quarterly, 31 379-387. doi:10.1016/j.giq.2013.12.006

\section{About the Author}

\section{Derek Lackaff}

Derek Lackaff is Assistant Professor at the School of Communications in Elon University, Elon, North Carolina. $\mathrm{He}$ is the founder of the Better Alamance Project (http://betteralamance.org), a civic technology collaboration focused on Alamance County, North Carolina. His research focuses on social media, civic technologies, creative industries, and the social psychology of communication technology use. He teaches in the iMedia (http://elon.edu/imedia) program at Elon University. 